\title{
Aqidah as a Basis of Social Tolerance: The Malaysian Experience
}

\author{
AHMAD MUNAWAR ISMAIL ${ }^{1}$
}

\begin{abstract}
The purpose of Islam is to develop exceptional human beings based on aqidah. Those with faith will have good life and will, in turn, have a positive influence on people around them. In Malaysia, aqidah forms the basis of Islamic education. Its main objective is to produce students who have Godconsciousness in all aspects of life. This survey was carried out by way of questionnaire among secondary school students. The interview method was also used with selected students, teachers and officers from the Ministry of Education. The paper will discuss the influence of aqidah on students in three parts. First is the extent of knowledge of aqidah among the students, second is the relationship between the knowledge of aqidah and students' social life, and finally, the impact of aqidah on students' behaviour. This paper concludes that aqidah has a great impact upon students' social activities.
\end{abstract}

Keywords: Aqidah, Tolerance, Higher Learning, Malaysia

The need for religion is innately present in every human being. This need is comprised of a number of aspects, namely instinct, sensory experience and feelings. Allah s.w.t created these aspects in order to guide humans into initiating a quest for knowledge that will ultimately benefit them. In themselves, the three aspects admit that humans are created weak and are therefore incapable of grasping matters beyond their reach. These aspects need to be developed by way of continuing education as well as having a clear set of guidelines in order to avoid confusion in life. This confusion will lead to humans exploring beliefs that suit their thoughts, whims and desires. Islam is sent to rectify this situation. Its aim is to develop and cater to every aspect of human needs based on creed (hereafter mentioned as aqidah), which is total faith in aspects regarding the divine, guidance and creed, or the conviction that Allah exists and that His orders must be followed without a shred of a doubt. It is this aqidah that will lead to the good life in this world and the next (Mahmud Syaltut 1966; Sayid Sabiq 2000). Neglect of these innate, fundamental aspects and their related characteristics will result in the decline of values to the point of them being contradictory to the basic norms of life (Haron Din et al. 1988). The significance of aqidah to our lives is evident during the first 13 years of revelation and spread of Rasululllah's message in Madinah. 13 years is a long period of time and the fact that the message and effort were focused on the basic Islamic creed is proof that this creed has extraordinary power in shaping human souls. The Qur'anic verses revealed at this period deal with the most basic of questions: the question of aqidah. They provide answers to questions pertaining to human's relationship with God, other human beings and the environment (Syed Muhammad Qutb 2003).

${ }^{1}$ Ahmad Munawar Ismail, Ph.D., Associate Professor at Department of Theology and Philosophy, Faculty of Islamic Studies, Universiti Kebangsaan Malaysia, 43600 BANGI, Selangor, Malaysia, email: munawar@ukm.edu.my.

https://doi.org/10.24035/ijit.1.2012.001 


\section{Background of the Study}

In Islam education goes beyond academia and examinations. It should be able to mould a person into an individual with such a profound knowledge of the approach of Islam that Islam becomes his guiding force. Awareness of Islamic principles is the basis for understanding Islamic teachings (Hassan 1987) and the basis of knowledge in Islam is aqidah because it is the force that prevents one from committing sins. The true aqidah can only be obtained through a combination of knowledge, dalil naqli (traditional proof) and logic (al-Ghazali 1939). In this regard, Tajul Ariffin dan Nor'Aini (2002) is of the view that the formation of a truly Muslim individual must begin with the development of aqidah because a strong aqidah will pave the way for high morals which would be realized through cognitive, affective and psychomotor. Said Ibrahim (1996) opined that learning and understanding aqidah are essential in moulding the mukmin kamil, that is, the perfect believer. Yusuf al-Qaradhawi (2000) meanwhile states that continuous efforts in building the aqidah in Muslim societies can shield attacks from nonbelievers and doubts from those who go astray. A society that has faith or aqidah as its guiding principle will be able to realize a good deed and later positively impact other individuals and societies. In a nutshell, knowledge of aqidah and the ability to understand it can create exceptional human beings, realizing their true potential as prescribed by Islam (al-Qaradhawi 1990; al-Qaradhawi 2000; Ibn Khaldun 2002; al-Ghazali 1939; Tajul Ariffin \& Nor 'Aini Dan 2002). In Malaysia, the emphasis in Islamic education is in integration, in particular the integration of knowledge, practice and appreciation. Students are provided with adequate information and thorough understanding about a variety of aspects of life which shape the lifestyle of the Muslim society (Kementerian Pendidikan Malaysia 2001; Tajul Ariffin \& Nor'Aini 2002). If we look at the scenario of Islamic education in Malaysia, whether through the historical point of view or a systematic point of view, combined with a systematic education programme, a comprehensive curriculum, supported by able educators trained in government-backed institutions, it can be assumed that Muslim students in Malaysia are capable of putting the Islamic knowledge that they have learned into practice, fulfilling the aspirations stated in the National Education Philosophy.

However, current trends among students do not reflect these ideals. The deterioration of morals and values among students is worrying. Wrongdoings and offences whether civil or syariah are reported almost daily in the mass media. Cases of apostasy (Farhan Abdullah 2006), the insults to Islam by way of the worst parts of Western culture such as Black Metal (Rohana 2005; Bahagian Pengurusan Dakwah JAIS 2005), alcohol consumption and suicide (Rohana Man 2004; Sadatul Mahiran 2005), brutality or vandalism (Adnan Abu Bakar \& Sidek Mohd Noah 2000) and many others appear on a regular basis in newspapers and the electronic media. Far from being isolated cases, these incidents are proof of the deterioration of values and this is admitted by members of the society including the country's leadership (Ibrahim 1995; Ungku Aziz 2005). Statistics show further evidence of this phenomenon. According to Hanina and Rozumah (2001), in 1998 as many as 81,929 secondary school students were involved in various wrongdoings and this figure increased to 96,538 in 1999. Most of the teenagers arrested were associated with antisocial groups, vandalism, delinquency and more precisely deviations. Rosnani Salleh (2002) and Kamarulnizam Abdullah (2003) discovered that moral delinquency among students is among the rise in all levels of school. This should not have been an issue considering the Islamic environment in the country. Muslims in Malaysia have been given considerable exposure to Islamic teachings through formal education as well as general

https://doi.org/10.24035/ijit.1.2012.001 
awareness. The fact remains that the calamity that befalls Muslim teenagers today is closely related to their faith, for it is hard to imagine a teenager with a strong faith being involved in drug abuse, adultery and the like. Therefore, a study about the role of aqidah in the education system is crucial to ensure that it can remain a tool to develop exemplary human beings besides creating an inner shield that can prevent teenagers from engaging in deviant acts wherever they are (al-Qaradhawi 1990; al-Qaradhawi 2000; Said Ibrahim 1996; Ibn Khaldun 2002; Al-Ghazali 1999; Zakaria Stapa 1997; Tajul Ariffin \& Nor 'Aini 2002).

\section{Methods}

This study is a descriptive one which utilizes the method of survey. The survey serves as the major instrument in the collection of data through randomly selected samples representing the population. The population for this survey consists of Form Four students learning the subject of Islamic Education, which numbered 257178 in all 1236 secondary schools in Malaysia (Kementerian Pendidikan Malaysia. 2001). Form Four students were chosen because they have generally passed the puberty stage (15 years of age) which is the starting point of having responsibilities (Abdullah Nasih 1995). Furthermore, these students have learned at least nine years of Islamic Education at the primary (KBSR) and secondary (KBSM) levels and are assumed to be able to evaluate their own knowledge and understanding of Islamic teachings. The method used in this survey is probability sampling. This method is used to ensure each respondent has equal representation in the survey (Ary et al. 1990). To carry out this sampling, layered random sampling technique (Wiersma et al. 2000) was used. The technique is used to ensure various categories of students are represented in this study. The chosen stratum for this study were Form Four students taking the subject of Islamic Education in national secondary schools based on the two categories of school set by the Ministry of Education, which are urban and non-urban. The sample units are chosen randomly by zones, namely Northern (Kedah), Southern (Melaka), Eastern (Terengganu) and Central (Selangor). However the percentage of the selected respondents are not decided by proportionate allocation due to the uneven number of students in the schools. In this study, researchers have determined the number of samples as suggested by Neuman (2003). According to Neuman, for large-scale surveys which involve populations more than 150000 , the number of samples needed is about one per cent of the total population and 1500 is appropriate for surveys of this size.

\section{Results \& Discussion}

An analysis of the findings of the survey on knowledge of aqidah among Muslim students in Malaysian secondary schools (which covered the basics of creed as well as belief in Allah, the messengers, the angels, the revelations, the Judgement Day and qada' and qadar) revealed that the respondents are reasonably well-informed on the subject matter in question. From a descending min score point of view, the concept of belief that scored the highest min is if the belief in Angels, followed by belief in the Books, Allah, the Messengers, Judgement Day, basics of creed and qada' and qadar (fate and destiny). The findings of this survey are in line with the Islamic teaching that regards creed as a highly crucial factor. Efforts in gaining knowledge and understanding Islamic creed are not a hobby or even a necessity but a direct command from Allah s.w.t to all Muslims (Wan Mohd Nor 1989). In this regard, Imam al-Ghazali states that the superiority and nobility of those with this type of knowledge are mentioned repeatedly in the Quran and the sayings of the Prophet and this fact is particularly apparent in Allah's placing of people with knowledge only after Himself and the angels (al-Ghazali 1939), which is evident in these verses: 
Allah bears witness that there is no god but He-and the angels, and men possessed of knowledge-upholding justice (3:18).

Allah will exalt in degree those of you who believe, and those who have been granted knowledge (58:11).

Al-Zabidi (1989) in explaining Imam al-Ghazali's interpretation of these verses affirms that the latter's ishtishhad in knowledge mentioned in the verses is the knowledge of the creed. According to al-Zabidi (1989) and Al-Sya'rawi (1991), verse 18 of surah Ali-Imran as mentioned previously demonstrates a close relationship between Allah's declaration of His own oneness and human's witness on Him. Humans must bear witness of this declaration through a process of pledge (iqamah) and learning (ta'lim) so that Allah's Oneness is acknowledged and brought into life, spiritually and practically (tatbiq) through moral obligations (Al-Zabidi 1989; Al-Sya'rawi 1991).

\section{Relationship between Students' Interest and Perception of Teaching and Learning of Aqidah and Their Knowledge of Aqidah}

It is revealed in the study that students have a positive interest and perception of the teaching and learning of aqidah. This reflects that students react positively to the teaching of aqidah in the subject of Islamic Education. The students' positive interest leads to them being well-versed in Islamic creed. This is shown by the value $r=0.400$ which displays a significant (positive) relationship between the teaching and learning of creed and students' knowledge of it. While this value is considered average, the value of sig. $=0.000$ suggests that improvement in students' interest and perception of the teaching and learning of aqidah will likewise increase their knowledge in the subject.

Further, the findings of the study correspond with the Woodsworth's (1940) theory which states that perception is a norm related to readiness and tendency to act upon an object according to how much we are used to it. In other words, perception is important in determining success in any endeavour and is highly influential in human tendencies. Bruner (1960) opines that in natural conditions humans are capable to learn by discovering the connections between numerous stimuli around them. According to him, this method could produce "intellectually enlightened" individuals through their own efforts. Outsiders only act as facilitators and provide suggestions without trying to change their perceptions. Concerning this, Crow and Crow (1983) are of the view that interest, skill and ability arise when one is driven by his perception. Perception has a profound interest on an individual. It can be the cause and effect of a behaviour; it is personal and affects one's feelings of one's experiences; it is reflected in the way one thinks, talks and acts. According to Za'ba (2005), knowledge gain and enrichment is not something inherited or gained through other people's prayers or the blessings from certain people but it comes from one's own effort, that is through knowledge and thought based on observing the Qur'an and the Prophet's sayings. He further states that humans are held responsible by what they believe and that they gain nothing that does not come from their effort.

Siti Rahayah (1988) in her survey asserts that there is significant connection between students' positive perception of a subject and their achievement in it. This finding agrees with that of a survey done quasi-longitudinal way about perception and achievement carried out by Abu Bakar Nordin and Salbiah Ismail (1991). This survey, which was carried out on 304 primary school pupils in Negeri Sembilan, shows that generally students who do well academically in a subject will have positive perception in that subject. The positive

https://doi.org/10.24035/ijit.1.2012.001 
signs recorded include students wanting to learn more about the subject, being ready to do tasks given and eagerly await the subject. On the other hand students who did not perform well in a subject show less interest in the subject, would rather do other things then do tasks related to the subject, and did not want to learn more about the subject. In a nutshell, studies on relationships between interest and perception show the importance of a positive interest and perception in achievement thus help increase knowledge which has the utmost importance in Islam in producing individuals who are well balanced and harmonious as well as possess high moral standards.

\section{Role of Creed in Students' Behaviour/Values/Morals}

The survey reveals that knowledge of aqidah contributed about $33.5 \%$ to the moral of students studying Islamic Education in national secondary schools. It also demonstrates that when the variable that is knowledge of aqidah increases by a unit the score of students' morals will show an increase of 0.6 units. This finding is supported by the method of interview, conducted to delve further into the role of aqidah in students' morals. Many of the students interviewed admitted that the knowledge of Islamic creed can improve their moral standards. They agreed that belief in the Book (al-Qur'an) and learning its contents particularly those about the major sins, life after death, judgement, and heaven and hell can help them be more conscious in life. A closer analysis reveals that while the respondents admit faith in the six articles of belief (Belief in Allah, belief in the Prophets and Messengers, belief in the Books, belief in the Angels, belief in the Day of Judgement and belief in qada' and qadar (Destiny), belief in God and the Day of Judgement get the most attention. The analysis is also in line with the finding that students have relatively high knowledge of aqidah.

The findings correspond with the statement made by Haron Din et al. (1988) which declares that the steps of producing exceptional human beings must begin with having the three basics of creed, which are belief in God Who possesses all kinds of perfection; second, belief in al-Qur'an which is the guide to be followed in all aspects of life; and third, belief in the Day of Judgement and Resurrection, in which all actions will be meticulously examined. These basics are called al-iltizam al-khuluqi, which means a system of morals that possess high energy and deep impact, and has such awesome power that it makes an individual conscious and vigilant by doing good deeds whether in public or in solitude in following Allah's command. This view parallels those expressed by many Islamic scholars such as Ibn Khaldun (t.t. 2002), al-Ghazali (1939), al-Sabiq (2000), Muhammad Nu'aim (1991), alQaradhawi (2001) and al-Bayanuni (2003) which state that knowledge and understanding of aqidah or Islamic creed will produce individuals with high moral standards. According to al-Ghazali (1939), people's morals are a reflection of how they think. How people think depends on how much knowledge they possess, and gaining knowledge whether good or bad depends on how much people are able to control their desires with their faith in Allah s.w.t. Al-Qaradhawi (1990) declares that knowledge is the path that leads to faith, and only those with true knowledge are able to deduce there is a higher power that creates the physical universe, taking care of it, having knowledge of all of it right to the minutest detail. Sharing similar point of view, Zakaria (1996) states that the faith of a Muslim may be gauged by his observations of the requirements of his belief. According to him, an exceptional individual is one who manages to direct all his actions towards pleasing Allah s.w.t. Al-Bayanuni (2003) meanwhile states that faith or creed is not merely an oral declaration but must be expressed through good deeds because faith and good deeds are two sides of the same coin. One cannot be considered as having faith if it is not accompanied 
by good deeds. Allah s.w.t says in the Quran (4:65): "By your Lord, they can have no faith until they make you judge in all disputes between them, and find in themselves no resistance against your decisions, and accept (them) with full submission".

Overall, this survey has managed to provide initial glimpse of the knowledge of aqidah and its relationship with the moral standards of students in secondary schools in Malaysia. With no intention to prove the truth of the Quran (Quranic truth is undisputed), this survey merely serves to provide scientific proofs of the opinions of the scholars regarding learning aqidah. It is hoped that the findings of this survey will have positive implications on how individuals should carry themselves in creating social tolerance in a multi-racial country like Malaysia.

\section{References}

Abdullah Nasih Ulwan. 1995. Pendidikan Kanak-Kanak dalam Islam. Transl. Syed Ahmad Semait. Singapore: Pustaka Nasional.

Abu Bakar Nordin \& Salbiah Ismail. 1991. Kesan pencapaian akademik kepada sikap terhadap mata pelajaran. Jurnal Psikologi Malaysia 7:41-60.

Ary. D, L. C. J. \& Asghar Razavieh. 1990. Introduction to Research in Education. United States: Holt, Rinehart \& Winston, Inc.

Adnan Abu Bakar \& Mohd Noah. 2000. Konsep kendiri di kalangan pelatih-pelatih institusi pemulihan kebajikan, Jabatan Kebajikan Masyarakat. Jurnal Kebajikan Masyarakat. 22(20):31-52.

Bahagian Pengurusan Dakwah, Jabatan Agama Islam Selangor (JAIS). 2005. Black Metal. Selangor: Bahagian Pengurusan Dakwah, Jabatan Agama Islam Selangor (JAIS) \& Angkatan Belia Islam Malaysia (ABIM) Selangor.

al-Bayanuni, Ahmad Izzuddin. 2003. Petunjuk Akidah Ahli Sunnah Wal Al-Jamaah. Transl. Hasnan Kasan. Kuala Lumpur: JAKIM.

Bruner, J.S. 1960. The Process of Education. New York: Vintage Books.

Crow, L.D. \& Crow, A. 1983. Psikologi Pendidikan untuk Perguruan. Transl. Habibah Alias. Kuala Lumpur: Dewan Bahasa dan Pustaka.

al-Ghazali, Abu Hamid. 1939. Ihya' 'Ulum al-Din. Juz. 1. Egypt: Matba`ah Mustafa al-Bab alHalabi.

al-Ghazzali, Muhammad. 1999. Khuluq al-Muslim. Alexandria: Dar al-Da`wah li al-Tab`i wa al-Nasyr wa al-Tauzi i.

Hanina Halimatusaadiah Hamsan \& Rozumah Baharuddin. 2001. Perkaitan pemantauan dan perhubungan ibubapa-anak dengan tahap tingkahlaku Devian remaja di Johor Bahru. Jurnal Kebajikan Masyarakat. 23(1): 1-12.

Haron Din (ed.). 1988. Manusia dan Islam. Kuala Lumpur: Percetakan Watan Sdn. Bhd.

Hassan Langgulung. 1987. Asas-asas Pendidikan Islam. Kuala Lumpur: Dewan Bahasa dan Pustaka.

Ibn Khaldun, Abd al-Rahman bin Muhammad Khaldun al-Hadrami. 2002. Mukaddimah Ibn Khaldun. Transl. Kuala Lumpur: Dewan Bahasa dan Pustaka.

Ibrahim Bakar. 1995. Pendidikan Islam di Malaysia dalam arus budaya korporat dan pembangunan manusia. Dlm. prosiding seminar kebangsaan, pendidikan negara abad ke-21. Bangi: Fakulti Pendidikan UKM.

Kamarulnizam Abdullah. 2003. Disiplin pelajar semakin menurun. Majalah Massa, Keluaran 12 September, Hlmn. 17.

Kementerian Pendidikan Malaysia. 1988. Falsafah Pendidikan Negara. Pusat perkembangan Kurikulum. 
Vol.1: (June) 2012

Kementerian Pendidikan Malaysia. 2001. Pembangunan Pendidikan 2001-2010: perancangan bersepadu penjana kecemerlangan pendidikan. Kuala Lumpur: Kementerian Pendidikan Malaysia.

Mahmud Syaltut.1966. Al-Islam, `Aqidah wa Syari ah. Cairo: Dar al-Qalam.

Mohd Farhan Abdullah. 2006. Kristianisasi dan gejala murtad di Malaysia. Seri Kembangan, Selangor: Al-Khidmah Resources.

Muhammad Nu aim Yasin. 1991. Al-Iman. Cairo: Maktabah al-Sunnah.

Neuman, W. L. 2003. Social Research Methods: Qualitative and Quantitative Approaches. 5th ed. USA : Pearson Education, Inc.

Rohana Man. 2004. Bunuh diri, Pelajar terpinggir dan terasing. (online) http://www.utusan.com.my [14 July 2005].

Rosnani Salleh. 2002. Pelaksanaan program sistem penalti dalam menangani masalah disiplin. Dissertation. Universiti Kebangsaan Malaysia. Unpublished.

al-Qaradhawi, Yusuf. 1990. Al-Iman wa al-Hayah. Cairo: Maktabah al-Wahbah.

al-Qaradhawi, Yusuf. 2000. Ciri-Ciri Unggul Masyarakat Islam Yang Kita Idamkan. Transl. Mohammad Zaini Yahya. Bandar Baru Bangi: As-Syabab Media.

al-Qaradhawi, Yusuf. 2001. Al-'Ibadah fi al-Islam. Beirut: Muassasah al-Risalah.

al-Qaradhawi, Yusuf. 2001. Fi Fiqh al-Aulawiyat Dirasah Jadidah fi Dhaui al-Quran wa alSunnah. Beirut: Muassasah al-Risalah.

al-Sabiq, Sayyid. 2000. al- Aqaid al-Islamiyyah. Cairo: al-Fath lil `Ilam al-Arabi.

Said Ibrahim. 1996. Akidah Ahli Sunnah wa al-Jamaah. Kuala Lumpur: JAKIM.

Sadatul Mahiran Rosli. 2005. Tujuh Kejadian Bunuh Diri Setiap Hari. Utusan Malaysia. 12 September.

Siti Rahayah Ariffin. 1988. Kajian mengenai sikap terhadap sains dan pencapaian dalam mata pelajaran sains paduan bagi pelajar-pelajar tingkatan 3. Disertasi. Universiti Kebangsaan Malaysia.

al-Sya rawi, Muhammad Mutawali. 1991. Tafsir al-Sy 'rawi. Jld. 3. Cairo: Akhbar al-Yaum.

Syed Muhammad Qutb. 2003. Petunjuk Sepanjang Jalan. Transl. Salahuddin Abdullah. Kuala Lumpur: Crescent News Sdn. Bhd.

Tajul Ariffin Noordin \& Nor'Aini Dan. 2002. Paradigma Pendidikan Bersepadu: Perkembangan Dua Dekad. In. Pendidikan dan Pembangunan Manusia. Bangi: Fakulti Pendidikan, UKM.

Ungku Aziz. 2005. Usaha Capai Keperibadian Unggul Bergantung kepada Diri Sendiri. Mingguan Malaysia. Ahad, 15 May.

Wan Mohd Nor Wan Daud. 1989. The Concept of Knowledge in Islam and Its Implicationsf for Education in a Developing Country. Great Britain: Mansell Publishing Limited.

Wiersma, W. 2000. Research Methods in Education: An Introduction. 7th ed. Boston: Allyn \& Bacon.

Woodworth, R.S. 1940. Psychology. $4^{\text {th }}$ ed. New York: Henry Holt and Company.

Za'aba, Zainal Abidin Ahmad. 2005. Perangai Bergantung Kepada Diri Sendiri. Kuala Lumpur: Dewan Bahasa dan Pustaka.

al-Zabidi, Murtadha Al-Sayyid Muhammad al-Husayni. 1989M/1409H. Itihap al-Qadah alMuttaqin bi Syarh Ihya Ulum al-Din. Juz.1. Beirut: Dar al-Kitab al-Ilmiah.

Zakaria Stapa. 1997. Akidah \& Akhlak dalam Kehidupan Muslim. Kuala Lumpur: Utusan Publications and Distributors Sdn. Bhd.

Zakaria Stapa. 1996. Konsep akidah dan pandangan al-Ghazali mengenai proses pendidikan akidah. In. Zakaria Stapa \& Mohamed Asin Dolah (ed.). Islam Akidah dan Kerohanian. Bangi: Penerbit UKM. 